\title{
Glioblastoma research: US and international networking achievements
}

\author{
David A. Groneberg ${ }^{1}$, Anna-Maria Addicks ${ }^{1}$, Michael H. Bendels ${ }^{1}$, David Quarcoo ${ }^{1}$, \\ Jenny Jaque ${ }^{2}$ and Dörthe Brüggmann ${ }^{1,2}$ \\ ${ }^{1}$ Division of Epidemiology, Institute of Occupational Medicine, Social Medicine and Environmental Medicine, Goethe-University, \\ Frankfurt, Germany \\ ${ }^{2}$ Department of Obstetrics and Gynecology, Keck School of Medicine of USC, Los Angeles, CA, USA
}

Correspondence to: David A. Groneberg, email: arbsozmed@uni-frankfurt.de

Keywords: glioblastoma, network, bibliometry, architecture, structure

Received: August 05, 2017

Accepted: September 03, 2017

Published: September 26, 2017

Copyright: Groneberg et al. This is an open-access article distributed under the terms of the Creative Commons Attribution License 3.0 (CC BY 3.0), which permits unrestricted use, distribution, and reproduction in any medium, provided the original author and source are credited.

\section{ABSTRACT}

\begin{abstract}
Being the most aggressive type of brain tumor, glioblastoma is estimated to be diagnosed in about 12,400 new cases in 2017 . The diagnosis is dramatic to patients and relatives and leaves open many unanswered questions for them. One is the big question why there is no cure as in other tumors. This review illustrates the US and global research efforts that have been made over the past century. It demonstrates the great magnitude of energy invested by US clinicians and scientists but undoubtedly, more research is needed and funding by NIH and other sources should be continued on the same level.
\end{abstract}

\section{INTRODUCTION}

US-American senator John McCain's diagnosis of glioblastoma left the nation in great sorrow and moved his fellow senators deeply, who prayed for him and his family. With an estimated 12,400 new cases being expected for 2017 by the Central Brain Tumor Registry this is the most common malignant brain tumor in the United States (US) [1]. Like most brain tumors types, the exact cause of glioblastoma is not known [2] leaving patients and their relatives in a desperate situation. A look into the most prestigious scientific journals such as the New England Journal of Medicine [3], Lancet [4, 5] or Journals of the American Medical Association [6] reveals an impressive number of scientific publications that have been published on this condition to date. A large number of basic and clinical studies have also been published in Oncotarget recently [7-19]. However, patients and their families are traumatized by the diagnosis. They have essential questions, which are also commonly shared by lawmakers and donors involved in healthcare policies and research funding: 1) Does a cure exist? 2) If not, why not? 3) Might there be a cure available in the next months? 4) What has the scientific community done to find new treatments? Have they done enough?

On the basis of a bibliometric platform that has been established a decade ago [20], we want to provide answers for the concerned public. This centenary review will share important first insights into the US-American and global achievements in the field of glioblastoma research. Our data reflect quantitative and qualitative aspects, chronological developments as well as collaborative networks and cover the time period from 1900 to 2008.

Great US research efforts from a global perspective

We used the New Quality and Quantity Indices in Science (NewQIS) platform [20, 21] to assess and visualize research productivity in an objective, reliable and standardized way. The platform combines scientometric methods and "density equalizing mapping projections" (DEMP) based on algorithms of Gastner and Newman [22] to draw anamorphic maps reflecting analyzed parameters.

A total of 14,411 publications were identified in the Web of Science using the search term "glioblastom*". The first article was identified in 1927; single publications followed in 1933, 1936, 1938 und 1940. Until the late 1960s we found a minor publication activity with less than ten articles published per year. In the next three decades the research output grew moderately; in 1990 authors published 76 publications per year. We noted the first dramatic increase in 1995 with 486 annual publications. 
Other productivity peaks followed in 1999 (720 annual articles) and 2008 (1500 annual publications).

Density equalizing procedures depict the domination of the global glioblastoma research by US scientists having authored a total of 6342 publications. The second most active country was Germany with 1937 glioblastomarelated articles followed by Japan (1422 articles). Research activity outside Northern America and Europe was extremely limited, e.g. authors from China, India and Brasil issued 278, 122 and 120 articles, respectively (Figure 1).

How often was this research cited by other publications? This is a surrogate for the quality of research. When the total number of citations was analyzed, the Unites States (US) again occupied the leading position. US-American publications were cited more than 180,000 times, indicating that the scientific community is heavily engaged in discussing the results obtained by US clinical and experimental research. Authors cited German articles 43,728 times, and Japanese articles 25,343 times. Also, articles by authors from Switzerland (21,503), France $(14,562)$, the UK $(13,493)$ Italy $(12,194)$ and Canada $(18,884)$ were well discussed (Figure 2). When the so called h-index was analyzed, the US glioblastoma research received the highest values with a h-index of more than 150, followed by Germany (87) and Switzerland (81). This specific index was named after J. Hirsch, who proposed a novel measure to quantify research output in $2005[23,24]$, and was adapted here to characterize the publication output of countries.

Impactful research is commonly produced in a joint effort. Ideally, the best clinicians and researchers come together to share resources and ideas aiming to advance the knowledge in the field. Therefore, insights into the global network of glioblastoma research are important. To analyze the glioblastoma research collaborations from a global perspective, affiliations of all authors were processed as earlier described [25, 26]: In brief, if two authors or more, originating from different countries, contributed to a glioblastoma-specific publication, this collaborative effort was recorded and visualized in a network diagram (Figure 3). Interactions between single pairs of countries were depicted by vectors, which were proportional in shades of grey and width to the number of bilateral collaborations $[25,26]$. Clearly, the US constituted the nucleus of global collaborative networks on glioblastoma research. In total, 1,289 out of all 6,342 US-American publications were performed within an international collaboration. Most prominent were collaborations between US-American and German authors (265 publications) followed by joint efforts between the US and Canada (169 publications), US and Japan (159 publications) and US and the United Kingdom (123 publications). In the past, international research was often performed bilaterally between neighboring countries. However, here we found the trend towards research collaborations between countries located far from each other. These sophisticated international networks are transcontinental and not limited by country borders. Collaborations are facilitated by modern communication systems and new computer technologies like the World Wide Web. These tools allow to communicate, exchange ideas and publicize articles in order to advance research in this field for the benefit of the patients and their families.

Which are the areas of highest research activity? This question is important for patients and also for donors.

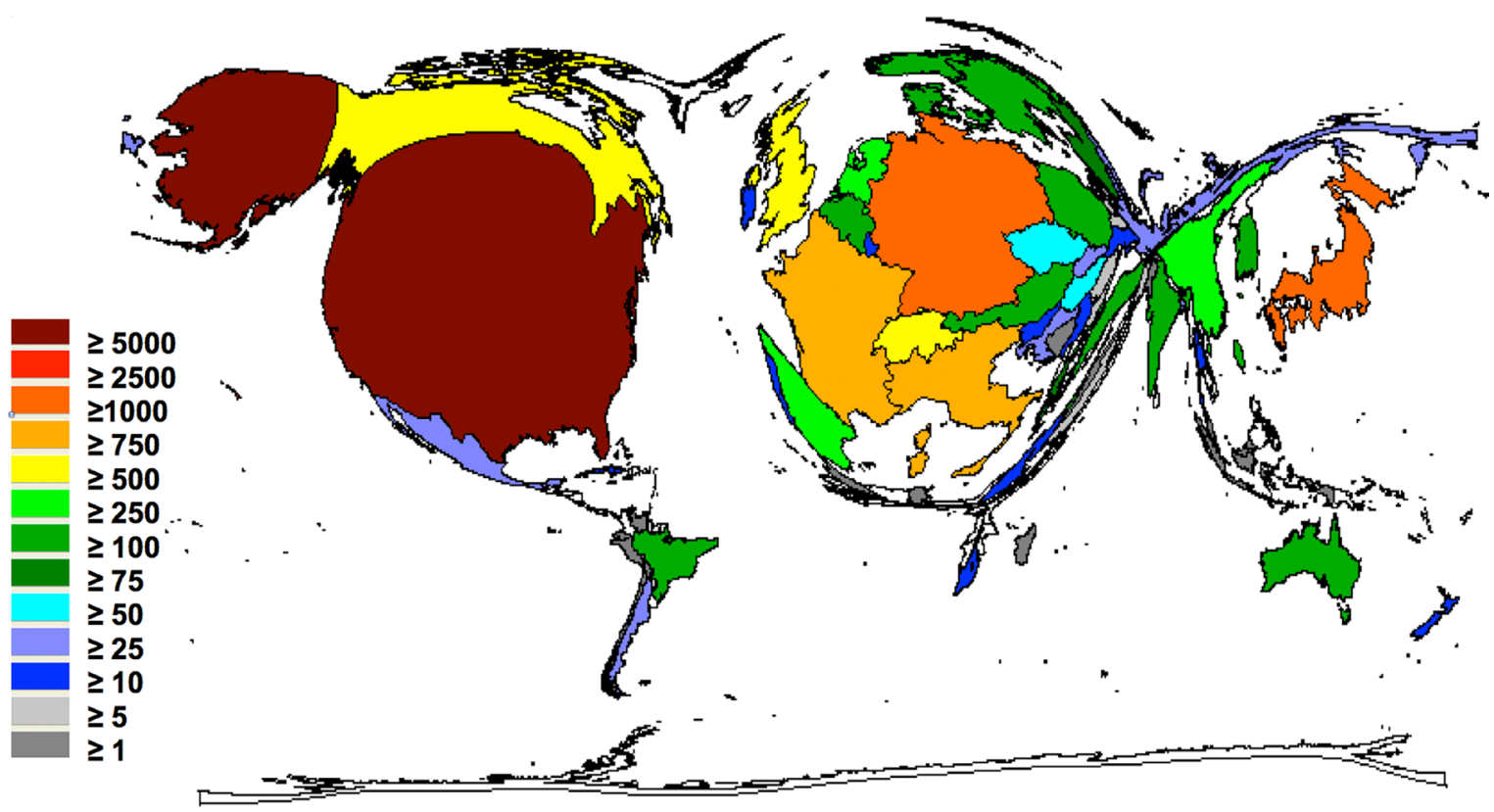

Figure 1: The global glioblastoma research activity. Density equalizing mapping of the global glioblastoma research activity assessed by publication output between 1900 and 2008. Colors and territorial sizes indicate numbers of glioblastoma publications per country. 
The subject areas of clinical neurology and oncology were the most prominent areas. This finding was not surprising. As depicted in Figure 4, there was a considerable overlap between these two fields. This finding indicates numerous interdisciplinary approaches, which also included the important aspects of surgery and diagnostics. Other prominent research fields include the areas of genetics, cell biology, or biochemistry and molecular biology. A high activity in the basic sciences is highly beneficial for the filed since it indicates a continuous interest of scientists to characterize pathogenetic mechanisms and to identify potential new therapeutic targets.
A further important question is: How did the funding landscape change throughout the years. From the present scientometric analysis, it is difficult to answer this question since funding sources of the 14,411 publications are not clearly indicated in every case in the database. Unfortunately, there are no registers that list all relevant project grants. However, single homepages list specific funding. A good example is the National Brain Tumor Society homepage (http://braintumor.org/ advance-research/funded-research-and-accomplishments/) that states [27]: "Since 1992, the National Brain Tumor Society has supported brain tumor research by directly
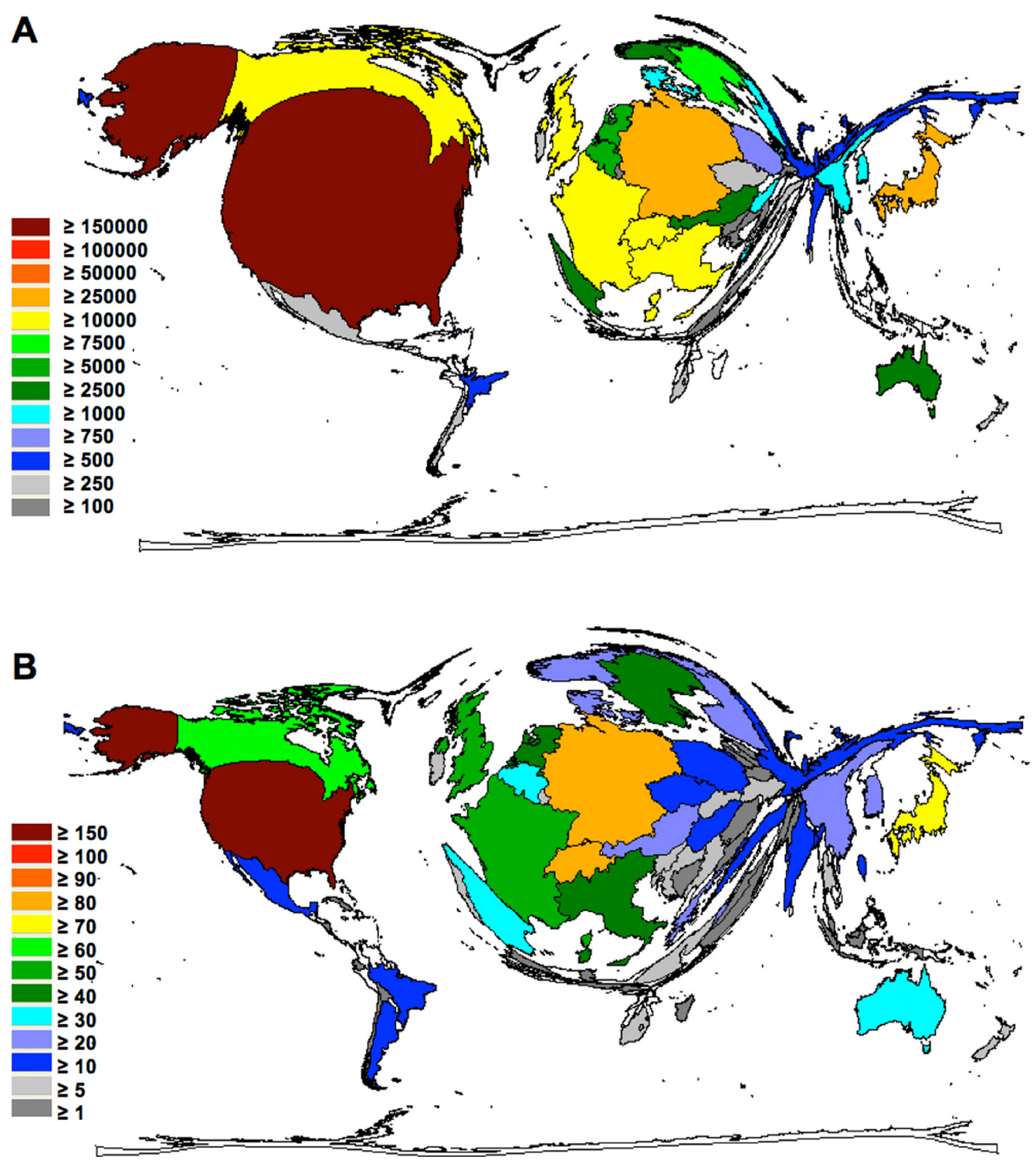

Figure 2: Density equalizing maps of the global glioblastoma research quality. (A) Colors and territorial sizes indicate total number of citations per country (B) Colors and territorial sizes indicate levels of glioblastoma-specific h-indices of countries 


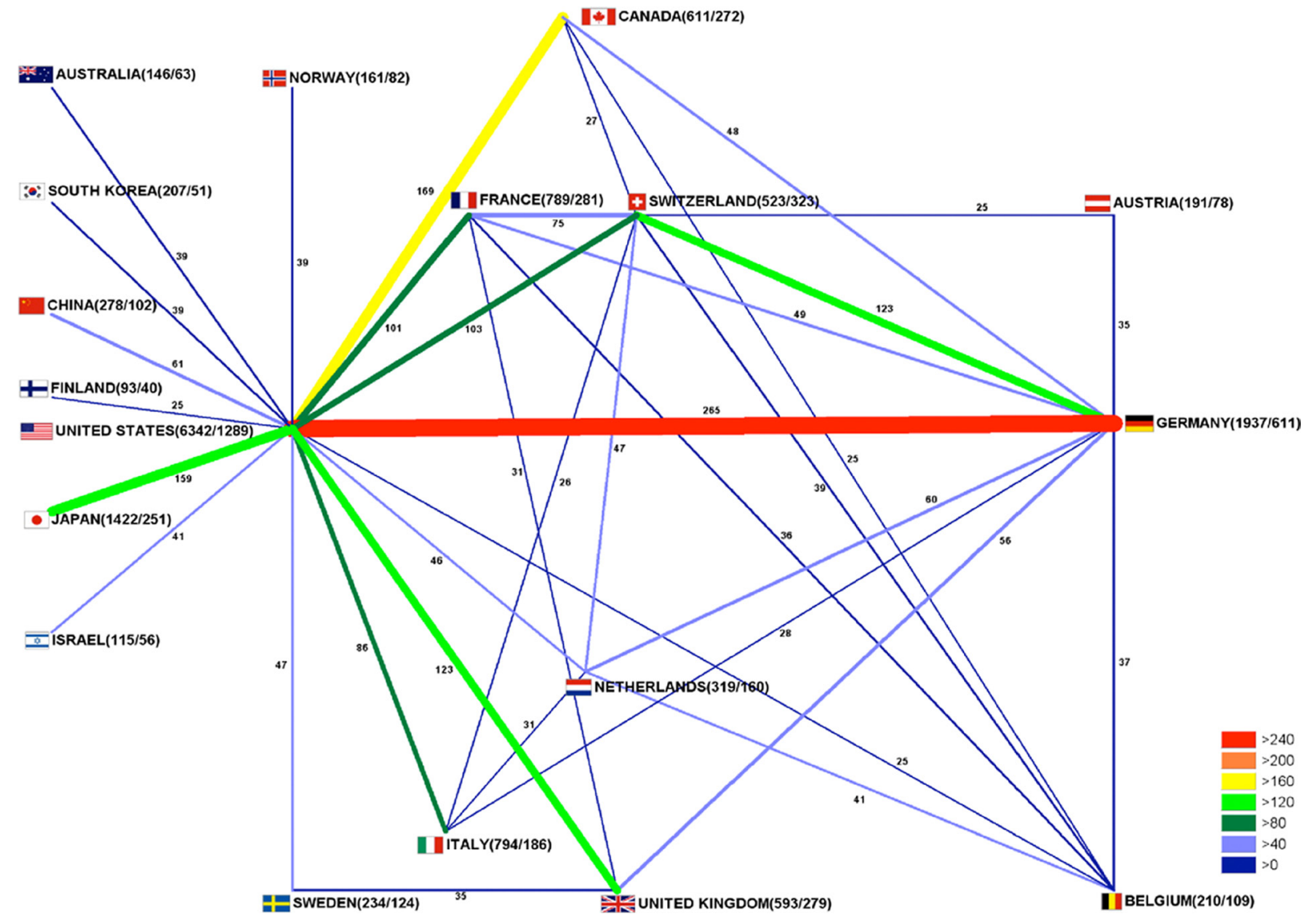

Figure 3: International glioblastoma research collaborations. Bar thickness indicates intensity of collaborations. First ciphers in brackets indicate total publication numbers. Second ciphers indicate number of collaborative publications.

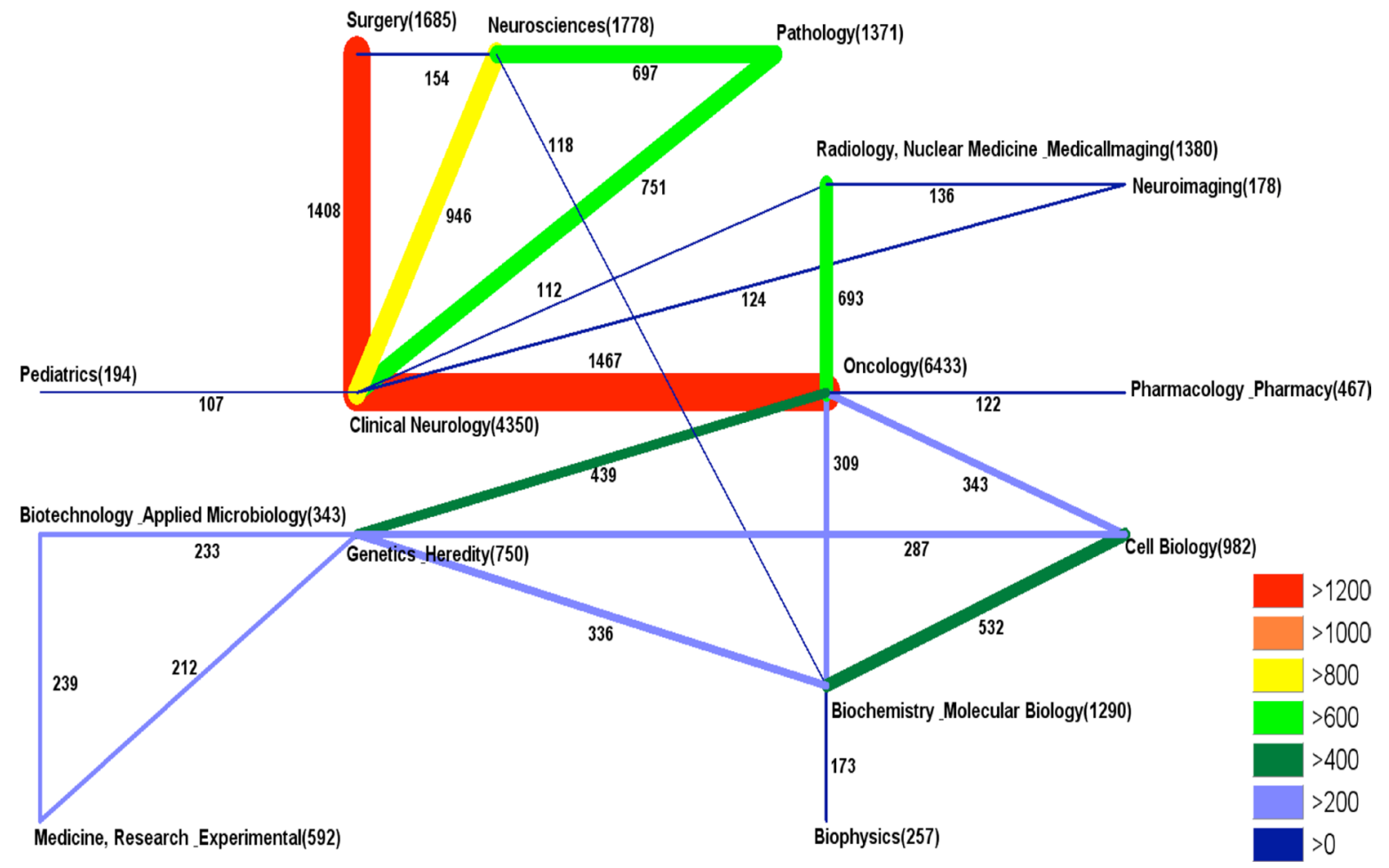

Figure 4: Glioblastoma research subject area analysis. 
funding grants itself, as well was collaborating with other funding organizations on various projects, including: the National Cancer Institute (NCI) Specialized Programs of Research Excellence (SPORE), the American Association for Cancer Research (AACR), the American Association of Neurological Surgeons (AANS), The Bridge Project, and the Brain Tumor Funders' Collaborative, and the Brain Tumour Foundation of Canada (...) It awarded more than \$31 million across 244 grants and grants have gone to organizations in: 30 of the 50 US states, Canada, Israel, The Netherlands. States that received the most funding have been: California, Massachusetts, North Carolina, New York, Pennsylvania, and Texas. The MD Anderson Cancer Center in Houston has received the most individual grants at $22.68 \%$ of the grants went to adult brain tumor research, while $22 \%$ went to pediatric brain tumor research. The largest percentage of the grants (59\%) went to the study of malignant gliomas (astrocytoma, brain stem glioma; DIPG, glioblastoma multiforme, oligodendroglioma, etc.) - the most dangerous brain tumors - and the rest were spread out among other tumor types" [27]. Ideally, a future study should assess global funding of glioblastoma research systematically. This can provide further rationale why $\mathrm{f}$ continuous funding to support glioblastoma research is needed.

\section{CONCLUSIONS}

In summary, this article represents the first centenary assessment of the world-wide glioblastoma research architecture. Using density-equalizing mapping techniques in combination with research quantity and quality indices, a global landscape of glioblastoma research was illustrated. Our data depicts an enormous research activity, which was mainly driven by US scientists and clinicians. Future research in the area should be fostered encompassing molecular biology [28-30], biochemistry [31, 32], morphologic [33-35], and pharmacologic $[36,37]$ techniques.

\section{Author contributions}

All authors have been involved in drafting and revising this review. All authors have read and approved the final manuscript.

\section{ACKNOWLEDGMENTS}

This work is dedicated to those who lost their lives in the fight against glioblastoma.

This study is part of a $\mathrm{PhD}$ thesis project (AMA).

\section{CONFLICTS OF INTEREST}

The authors declare that they have no conflicts of interest.

\section{REFERENCES}

1. Central Brain Tumor Registry of the United States. 2017.

2. American Brain Tumor Association: Glioblastoma. 2017.

3. Gilbert MR, Dignam JJ, Armstrong TS, Wefel JS, Blumenthal DT, Vogelbaum MA, Colman H, Chakravarti A, Pugh S, Won M, Jeraj R, Brown PD, Jaeckle KA, et al. A randomized trial of bevacizumab for newly diagnosed glioblastoma. N Engl J Med. 2014; 370:699-708.

4. Weller M, van den Bent M, Hopkins K, Tonn JC, Stupp R, Falini A, Cohen-Jonathan-Moyal E, Frappaz D, Henriksson R, Balana C, Chinot O, Ram Z, Reifenberger G, et al, and European Association for Neuro-Oncology (EANO) Task Force on Malignant Glioma. EANO guideline for the diagnosis and treatment of anaplastic gliomas and glioblastoma. Lancet Oncol. 2014; 15:e395-403.

5. Stupp R, Hegi ME, Gorlia T, Erridge SC, Perry J, Hong YK, Aldape KD, Lhermitte B, Pietsch T, Grujicic D, Steinbach JP, Wick W, Tarnawski R, et al, and European Organisation for Research and Treatment of Cancer (EORTC), and Canadian Brain Tumor Consortium, and CENTRIC study team. Cilengitide combined with standard treatment for patients with newly diagnosed glioblastoma with methylated MGMT promoter (CENTRIC EORTC 2607122072 study): a multicentre, randomised, open-label, phase 3 trial. Lancet Oncol. 2014; 15:1100-1108.

6. Zarnett OJ, Sahgal A, Gosio J, Perry J, Berger MS, Chang S, Das S. Treatment of elderly patients with glioblastoma: a systematic evidence-based analysis. JAMA Neurol. 2015; 72:589-596.

7. Alkharusi A, Yu S, Landázuri N, Zadjali F, Davodi B, Nyström T, Gräslund T, Rahbar A, Norstedt G. Stimulation of prolactin receptor induces STAT-5 phosphorylation and cellular invasion in glioblastoma multiforme. Oncotarget. 2016; 7:79572-83. https://doi.org/10.18632/oncotarget.12840.

8. Gao X, Mi Y, Guo N, Hu Z, Hu F, Liu D, Gao L, Gou X, Jin W. Disrupted in schizophrenia 1 (DISC1) inhibits glioblastoma development by regulating mitochondria dynamics. Oncotarget. 2016; 7:85963-74. https:/doi. org/10.18632/oncotarget.13290.

9. Giese M, Turiello N, Molenda N, Palesch D, Meid A, Schroeder R, Basilico P, Benarafa C, Halatsch ME, Zimecki M, Westhoff MA, Wirtz CR, Burster T. Exogenous cathepsin G upregulates cell surface MHC class I molecules on immune and glioblastoma cells. Oncotarget. 2016; 7:74602-11. https://doi.org/10.18632/oncotarget.12980.

10. Kanabur P, Guo S, Simonds GR, Kelly DF, Gourdie RG, Verbridge SS, Sheng Z. Patient-derived glioblastoma stem cells respond differentially to targeted therapies. Oncotarget. 2016; 7:86406-19. https://doi.org/10.18632/oncotarget.13415.

11. Lee DH, Ryu HW, Won HR, Kwon SH. Advances in epigenetic glioblastoma therapy. Oncotarget. 2017; 8:18577-89. https://doi.org/10.18632/oncotarget.14612.

12. Nabissi M, Morelli MB, Arcella A, Cardinali C, Santoni M, Bernardini G, Santoni A, Santoni G, Amantini C. Posttranscriptional regulation of 5 '-untranslated regions of human Transient Receptor Potential Vanilloid type-1 
(TRPV-1) channels: role in the survival of glioma patients. Oncotarget. 2016; 7:81541-54. https://doi.org/10.18632/ oncotarget. 13132.

13. Pavon LF, Sibov TT, de Oliveira DM, Marti LC, Cabral FR, de Souza JG, Boufleur P, Malheiros SM, de Paiva Neto MA, da Cruz EF, Chudzinski-Tavassi AM, Cavalheiro S. Mesenchymal stem cell-like properties of CD133+ glioblastoma initiating cells. Oncotarget. 2016; 7:40546-57. https://doi.org/10.18632/ oncotarget.9658.

14. Rong X, Huang B, Qiu S, Li X, He L, Peng Y. Tumorassociated macrophages induce vasculogenic mimicry of glioblastoma multiforme through cyclooxygenase-2 activation. Oncotarget. 2016; 7:83976-86. https://doi. org/10.18632/oncotarget.6930.

15. Sulzmaier FJ, Young-Robbins S, Jiang P, Geerts D, Prechtl AM, Matter ML, Kesari S, Ramos JW. RSK2 activity mediates glioblastoma invasiveness and is a potential target for new therapeutics. Oncotarget. 2016; 7:79869-84. https://doi.org/10.18632/oncotarget.13084.

16. Tian T, Mingyi M, Qiu X, Qiu Y. MicroRNA-101 reverses temozolomide resistance by inhibition of GSK3beta in glioblastoma. MicroRNA-101 reverses temozolomide resistance by inhibition of GSK3 $\beta$ in glioblastoma. Oncotarget. 2016; 7:79584-95. https://doi.org/10.18632/ oncotarget. 12861.

17. Vartanian A, Agnihotri S, Wilson MR, Burrell KE, Tonge PD, Alamsahebpour A, Jalali S, Taccone MS, Mansouri S, Golbourn B, Aldape KD, Zadeh G. Targeting hexokinase 2 enhances response to radio-chemotherapy in glioblastoma. Oncotarget. 2016; 7:69518-35. https://doi.org/10.18632/oncotarget.11680.

18. Yang SH, Li S, Lu G, Xue H, Kim DH, Zhu JJ, Liu Y. Metformin treatment reduces temozolomide resistance of glioblastoma cells. Oncotarget. 2016; 7:78787-803. https:// doi.org/10.18632/oncotarget.12859.

19. Zhu P, Du XL, Lu G, Zhu JJ. Survival benefit of glioblastoma patients after FDA approval of temozolomide concomitant with radiation and bevacizumab: A populationbased study. Oncotarget. 2017; 8:44015-31. https://doi. org/10.18632/oncotarget.17054.

20. Groneberg-Kloft B, Quarcoo D, Scutaru C. Quality and quantity indices in science: use of visualization tools. EMBO Rep. 2009; 10:800-803.

21. Groneberg-Kloft B, Fischer TC, Quarcoo D, Scutaru C. New quality and quantity indices in science (NewQIS): the study protocol of an international project. J Occup Med Toxicol. 2009; 4:16.

22. Gastner MT, Newman ME. Diffusion-based method for producing density-equalizing maps. Proc Natl Acad Sci U S A. 2004; 101:7499-7504.

23. Hirsch JE. An index to quantify an individual's scientific research output. Proc Natl Acad Sci U S A. 2005; 102:16569-16572.

24. Hirsch JE. Does the H index have predictive power? Proc Natl Acad Sci U S A. 2007; 104:19193-19198.

25. Carl J, Schwarzer M, Klingelhoefer D, Ohlendorf D, Groneberg DA. Curare- a curative poison: a scientometric analysis. PLoS One. 2014; 9:e112026.
26. Mund M, Kloft B, Bundschuh M, Klingelhoefer D, Groneberg DA, Gerber A. Global research on smoking and pregnancy-a scientometric and gender analysis. Int $\mathrm{J}$ Environ Res Public Health. 2014; 11:5792-5806.

27. National Brain Tumor Society: Funded Research and accomplishments. 2017.

28. Gao YF, Mao XY, Zhu T, Mao CX, Liu ZX, Wang ZB, Li L, Li X, Yin JY, Zhang W, Zhou HH, Liu ZQ. COL3A1 and SNAP91: novel glioblastoma markers with diagnostic and prognostic value. Oncotarget. 2016; 7:70494-503. https:// doi.org/10.18632/oncotarget.12038.

29. Springer J, Scholz FR, Peiser C, Groneberg DA, Fischer A. SMAD-signaling in chronic obstructive pulmonary disease: transcriptional down-regulation of inhibitory SMAD 6 and 7 by cigarette smoke. Biol Chem. 2004; 385:649-653.

30. Groneberg DA, Doring F, Nickolaus $M$, Daniel $H$, Fischer A. Expression of PEPT2 peptide transporter mRNA and protein in glial cells of rat dorsal root ganglia. Neurosci Lett. 2001; 304:181-184.

31. Podergajs N, Motaln H, Rajčević U, Verbovšek U, Koršič M, Obad N, Espedal H, Vittori M, Herold-Mende C, Miletic H, Bjerkvig R, Turnšek TL. Transmembrane protein CD9 is glioblastoma biomarker, relevant for maintenance of glioblastoma stem cells. Oncotarget. 2016; 7:593-609. https://doi.org/10.18632/oncotarget.5477.

32. Feleszko W, Zawadzka-Krajewska A, Matysiak K, Lewandowska D, Peradzynska J, Dinh QT, Hamelmann E, Groneberg DA, Kulus M. Parental tobacco smoking is associated with augmented IL-13 secretion in children with allergic asthma. J Allergy Clin Immunol. 2006; 117:97-102.

33. D'Alessio A, Proietti G, Lama G, Biamonte F, Lauriola L, Moscato U, Vescovi A, Mangiola A, Angelucci C, Sica G. Analysis of angiogenesis related factors in glioblastoma, peritumoral tissue and their derived cancer stem cells. Oncotarget. 2016; 7:78541-56. https://doi.org/10.18632/ oncotarget.12398.

34. Peiser C, Springer J, Groneberg DA, McGregor GP, Fischer A, Lang RE. Leptin receptor expression in nodose ganglion cells projecting to the rat gastric fundus. Neurosci Lett. 2002; 320:41-44.

35. Dinh QT, Groneberg DA, Peiser C, Springer J, Joachim RA, Arck PC, Klapp BF, Fischer A. Nerve growth factorinduced substance $\mathrm{P}$ in capsaicin-insensitive vagal neurons innervating the lower mouse airway. Clin Exp Allergy. 2004; 34:1474-1479.

36. Ghoochani A, Yakubov E, Sehm T, Fan Z, Hock S, Buchfelder M, Eyupoglu IY, Savaskan NE. A versatile ex vivo technique for assaying tumor angiogenesis and microglia in the brain. Oncotarget. 2016; 7:1838-53. https:// doi.org/10.18632/oncotarget.6550.

37. Eynott PR, Groneberg DA, Caramori G, Adcock IM, Donnelly LE, Kharitonov S, Barnes PJ, Chung KF. Role of nitric oxide in allergic inflammation and bronchial hyperresponsiveness. Eur J Pharmacol. 2002; 452:123-133. 